\title{
Modelos teóricos da comunicação e da linguagem aplicados ao design gráfico
}

\author{
Theoretical models of communication and language applied to graphic design
}

\author{
Santos, Fátima Aparecida dos; Doutora; \\ Universidade de Brasilia \\ designfatima@uol.com.br
}

\begin{abstract}
RESUMO
O presente artigo traz uma proposta para pensar o design gráfico a partir da adequação dos modelos teóricos da comunicação elaborados pelo lingüísta Roman Jakobson e o semioticista luri Lotman. Ao designer cabe organizar a mensagem de tal forma que ela fique atrativa, relevante e que a informação seja percebida pelo usuário. A proposta expressa neste artigo pretende recuperar e posicionar essas relações entre mensagem, linguagens, informação e design, percebendo como a mensagem pensada pelo prisma do design pode conduzir o olhar. Busca-se uma aproximação entre as teorias propostas e o trabalho do designer no que tange a construção de mensagens. Utiliza-se a análise proposta por Jakobson para pensa a organização sintática de trabalhos gráficos levando em consideração que o mesmo utiliza-se de várias linguagens. Partindo do pressuposto de que não existe linguagem que não influencie ou seja influenciada pela cultura, conclui-se o artigo relacionando o modelo comunicacional gerado a partir dos estudos de Jakobson com o poliglotismo da cultura propostos por luri Lotman.
\end{abstract}

Palavras-chave: design. Modelos teóricos. Linguagens. Comunicação.

\begin{abstract}
The present paaer have a proposal to think the graphic design starting from the adaptation of the theoretical communication models elaborated by Roman Jakobson and Iuri Lotman. To the designer it fits to organize the message in such a way to be attractive, relevant and that the information is noticed by the user. The expressed proposal in this paper intends to recover and to position those relationships among message, languages, information and design, noticing as the message thought by the prism of the design can drive the glance. An approach is looked for between the proposed theories and the work of the designer with respect to construction of messages. The analysis is used proposed by Jakobson for leaning the syntactic organization of graphic works taking into account that the same is used of several languages. Leaving of the presupposition that language that doesn't influence doesn't exist or be influenced by the culture, the article is concluded relating the communication model generated starting from the studies of Jakobson with the poliglotismo of the culture proposed by luri Lotman.
\end{abstract}

Palavras-chave: design. Modelos teóricos. Linguagens. Comunicação.

\section{Introdução}

A linguagem opera como uma estrutura que diferencia a natureza dos objetos ou dos signos. É através do reconhecimento das estruturas de linguagem que se pode interpretar, refazer e fazer significar. Significar ou organizar representações é o objetivo máximo dos processos de comunicação. Um dos objetivos do design é comunicar, logo deve existir um conjunto de linguagens que permitam transformar pensamentos em mensagens visuais. Prolonga-se neste artigo o texto publicado no livro "Linguagens do web design"1 no qual se mapeou as sintaxes utilizadas na Internet e verificou-se a capacidade de informação das mensagens produzidas para essa mídia. A teoria de base foi o trabalho 
do linguísta russo Roman Jakobson sobre as funções da linguagem na qual ele desenvolve o conceito que descreve o modo de transformar pensamento em texto.

Todo signo lingüístico implica dois modos de arranjo:

1-) A combinação. Todo signo é composto de signos constituintes e ou aparece em combinação com outros signos. Isso significa que qualquer unidade lingüística serve ao mesmo tempo, de contexto em uma unidade lingüística mais complexa. Seguese daí que todo argumento efetivo de unidades lingüísticas liga-as numa unidade superior: combinação e contextura são as duas faces de um mesma operação.

2-) A seleção. Uma seleção entre termos alternativos implica a possibilidade de substituir um pelo outro, equivalente ao primeiro num aspecto e diferente em outro. De fato, seleção e substituição são as duas faces de uma mesma operação. (JAKOBSON, 1991, 39)

Os dois modos de arranjos do autor não solucionavam as particularidades das páginas da internet e, por isso, propôs-se um terceiro modo ou o arranjo pela sobreposição de linguagens. A elaboração de uma página de internet necessita da seleção de elementos do repertório do designer, da combinação desses elementos e da sobreposição desses elementos em uma tela, além é claro dos diversos processos de emulação para que ela se apresente ao usuário. Logo, no livro Linguagens do web design o que se propõe é pensar as mídias digitais enquanto elaboração de mensagem e para isso é necessário selecionar e codificar os diversos tipos de códigos de linguagens existentes nessa mídia, o verbal, o imagético e o sonoro, cada um ao seu tempo. Cada uma dessas representações para efetivarem seu potencial como mensagens deveriam obedecer as etapas de elaboração e, após a conclusão de todas as etapas, o trabalho do designer consiste, nesse recorte, em sobrepor ou organizar a mensagem verbal, construindo uma relação com imagens, fotografias e animação e até mesmo com os efeitos sonoros. Essas relações e sobreposições garantem a existência de intertextualidade no ambiente digital e também potencializam o hipertexto.

Se uma página de internet for composta por duas linguagens, visual e sonora, existe um processo de seleção e combinação dos signos sonoros e um processo dos signos visuais. Os dois arranjos são sobrepostos gerando a mensagem final. A formação de mensagens sem a observação da sobreposição resulta em duas mensagens diferentes disputando a atenção do receptor. Todo arranjo que envolva mais de uma linguagem pode ser pensado a partir da relação: seleção, combinação e sobreposição.

Se existe a possibilidade de ler design como sobreposição de linguagens é necessário pensar um pouco sobre seus códigos. O mapeamento dos principais códigos de design revela princípios de organização e linguagem, pois é a partir do entendimento da particularidade de cada um deles que as linguagens do design se revelam em toda a sua plenitude e complexidade.

Pode-se comparar design ao modelo de comunicação proposto por Jakobson $(1995$, p.123) posicionando sua função enquanto emissor; as relações e capacidades de vínculo e associações dos usuários.

Os signos do design funcionam como uma forma de conduzir a informação disponível na cultura até o usuário. Uma espécie de jogos estéticos de reconstrução de sentidos ao mesmo tempo únicos porque pertencem ao indivíduo, e coletivos porque somam-se a cultura.

Por isso entende-se design como um sistema codificado ou como o mecanismo que permite gerar sentidos por meio da soma de várias linguagens conforme se analisará mais adiante.

Ao pensar o sistema design, naturalmente, depara-se com um conjunto de códigos que passam pela linguagem das cores, formas, volumes, tipografias, etc. Os códigos no design funcionam como a interface entre o design e os outros sistemas. De certa maneira a complexidade desse pensamento reside em uma função de interface porque design é elemento de comunicação.

\section{Linguagens e códigos do design}

Entender design gráfico como um conjunto de linguagens abre a possibilidade de conectar 
vários processos de aprendizagem, métodos e técnicas para ensiná-lo como uma grande composição de textos e não apenas como talento ou a junção de conhecimentos desconexos. Pensando em linguagem gráfica, procura-se traduzi-la na língua natural e nesse processo não encontramos elementos que desempenhem a mesma função. Cada letra opera como fator de diferenciação no processo de elaboração de uma mensagem em linguagem verbal.

Decompondo-se a linguagem verbal em partículas mínimas a diferença constitui-se como elemento de informação. Jakobson (1995, p.38) diz que no 'código existe uma partícula distintiva', ou a unidade na qual reside a diferença. A unidade mínima da linguagem escrita é a letra, cuja capacidade de significação só se dá quando combinada, organizada em sistema, compondo palavras e estas compondo textos. Existem letras que têm significado, de acordo com a sua função no texto, quando pronuncia a letra "o" espera-se um complemento para a frase, mentalmente aparecem possibilidades "o menino, o gato, o rato, etc", mas se pronunciamos "j" o mesmo processo não acontece.

(...)tal conjunto de possibilidades já previstas e preparadas implica a existência de um código, e esse código é concebido pela teoria da comunicação como "uma transformação convencionada, habitualmente de termo a termo reversível", por meio da qual um dado conjunto de unidades de informação se converte em outros...O código combina o signans (significante) como o signatum (significado) e estes com aquele. (JAKOBSON, 1971 p.76)

A potencialidade de informação característica da linguagem verbal foi explorada em um anúncio, composto por duas fotografias iguais de uma poltrona vazia em um escritório, abaixo das fotos frases, contendo as mesmas características tipográficas, em letras miúdas incitam o receptor a diferenciar as duas imagens. As frases "só chega às 11: ta podendo" e "só chega às 11: ta pedindo" faziam com que as duas imagens, embora iguais, fossem lidas de modo diferente. Neste caso, o pedindo e o podendo, apesar de estruturas próximas, continuam diferenças em sinais ou códigos discretos. É possível quebrar a palavra pedindo em $p$-e-d-i-n-d-o e perceber a diferença entre "o" e " $e$ " e entre "e" e "i". Mas com quais códigos, discretos ou não, um designer precisa escrever?

Os currículos das escolas definem uma série de disciplinas que dão pistas de quantas e quais linguagens um designer precisa aprender para fazer significar. A HFG criou uma série de procedimentos na área de design, influenciou várias gerações e suas marcas podem ser percebidas até hoje. Seu currículo era composto de disciplinas que iam de ciência das cores à antropologia cultural, de introdução à sociologia à laboratório de impressão, de estrutura de exposição e embalagens à semiótica, de sociodinâmica da cultura à cibernética (WOLNER, 2003, p.80). O Brasil herdou algumas das disciplinas implantadas pela Bauhaus e depois pela HfG. Entretanto, em muitas escolas brasileiras, as disciplinas são ministradas isoladamente e espera-se que a convergência entre as diversas linguagens, conhecimentos e aprendizagens, aconteça durante a concepção dos projetos. Logo, buscar as formas como as linguagens do design podem ser sobrepostas auxiliará no ensino de projetos e nas relações entre o design e outros fazeres.

Retomando a discussão sobre códigos discretos e não discretos, pensamos que se as palavras podem ser decompostas em letras, as imagens podem ser decompostas em formas, cores e volumes.

Propomos observar alguns dos elementos que compõem o design gráfico observando-os como códigos:

\section{A forma}

A linguagem matemática permite descrever formas com precisão, sabendo que o processo de codificação e decodificação resulta em uma representação semelhante. Basicamente todas as formas podem ser decompostas em figuras geométricas básicas e essas podem ser enunciadas através de formulas que são ensinadas nas escolas. Assim, a área de um quadrado é $l^{2}$, a de um retângulo é $h x l$ e um triângulo retângulo também pode ser escrito como (bxh):2. A área de um círculo pode ser descria como $2 \Pi \mathrm{R}^{2}$, onde $\Pi$ equivale ao número 3.141516 e $\mathrm{R}$ a medida do raio (distância entre o centro e o contorno da círculo). Pode-se descrever a circunferência como um ponto que deslizou em torno de um 
outro ponto central, mas isso não a reconstitui, codifica e não codifica novamente da mesma maneira. A geometria é em uma das linguagens do design e através dela pode-se decompor todo e qualquer forma em estruturas geométricas.

\section{Cor}

Se a geometria consegue operar como uma possível codificação para a forma, a cor tem pelo menos três formas de codificação, pois, se decompõe fisicamente, quimicamente e fisiologicamente. Fisicamente de acordo com a iluminação, quimicamente para composição de tintas e fisiologicamente como resultado do processamento de percepção da luz pelos olhos. As cores básicas diferenciam-se para cada uma das composições citadas.

As primárias fundamentais são as cores básicas que emocionam as células perceptivas dos olhos conhecidos como cones. Por processarem informação os cones também são considerados neurônios especializaram-se em diferenciar as ondas de luz. Para traduzir a sensação de cor em processos de impressão, existe o sistema CMYK, também conhecido como subtração cromática, nele um certo pigmento opera como filtro anulando o efeito de outras ondas de cor refletindo apenas o seu tom. Na direção oposta tem se a adição cromática que acontece a partir da emissão de luz, nesse sistema as cores primárias são o verde, o vermelho e o azul, também representados pelas letras RGB. No sistema CMYK, o mais utilizado pelo design impresso, o processo de codificação de uma cor se dá pela porcentagem de cada um dos pigmentos, assim, C60 M 80 YO e K0 é entendido por toda comunidade gráfica como um tom de roxo, por outro lado, C0 M100 Y100 e K0 será decodificado como cor de laranja.

Os conjuntos de possibilidades descritos acima não representam todos os sistemas de codificação de cores. Existe ainda o sistema Pantone, onde as cores são representadas por uma espécie de nome próprio e para utilizá-lo é necessário saber o significado de cada termo, não constitui, portanto uma espécie de código. Outro mais complexo é o sistema Munsell, representado por dois cones sobrepostos com emissão de luz na parte superior e ausência na parte inferior. Embora seja muito complexo para ser utilizado no dia a dia esse sistema permite verificar combinações de tons que se dão por matiz, saturação, brilho, etc.

\section{Cor e forma}

Ao sobrepor forma e cor, os processos de elaboração são distintos e têm um ordenamento, na elaboração do desenho de uma laranja, por exemplo, não é possível aplicar cor antes de ter o desenho pronto.

\section{A fotografia}

A fotografia é uma linguagem utilizada na elaboração de diversos designs gráficos. Apesar da tecnologia para fotografar ter mudado muito nos últimos anos, chegando o ponto da existência de fotografia sem papel ou mesmo filme fotográfico, ela continua existindo na sua essência, ou seja, um desenho feito com luz. Logo o grande elemento de composição da fotografia é a diferença entre claro e escuro, áreas de sombra e áreas de luz que definem o volume e, portanto, permite representar o objeto fotografado. Para que se obtenha um bom resultado é necessário dominar a técnica fotográfica que consiste em entender e interpretar como a luz consegue entrar no interior da câmera. Os elementos abertura, velocidade e foco, controlam a luz e resultarm em representações diferenciadas. A sensibilidade do filme também opera como um fator de diferenciação da imagem. A fotografia em sua origem não possuía o que Lotman $(1989$, p.73) chamou de código discreto porém a medida em que novas tecnologias foram surgindo a luz, elemento essencial da fotografia, passou a ser representada por meio dos códigos binários em máquinas fotográficas digitais. A ampliação de qualquer fragmento digital permite verificar como o processo de digitalização da imagem transforma informações como luz e sombra em um conjunto de códigos discretos possíveis de serem organizados em um sistema de coordenadas.

A fotografia em muitos casos é utilizada com o objetivo de garantir ao receptor que a 
imagem apresentada tenha uma relação de semelhança muito grande com o objeto de origem. Ela tem funcionado também como base para elaboração de desenhos. Alguns profissionais fotografam objetos, digitalizam a imagem e transformam-na em uma espécie de representação às avessas, tal processo permite suavizar as relações de semelhança e por outro lado é também a tradução de uma linguagem em outra, fotografia transformada em desenho.

\section{Tipografia}

No extremo oposto às formas, cores e fotografias está a tipografia, podemos considerá-la como um sistema à parte, pois a compreensão dessa linguagem utilizada pelos designers necessita entender um pouco do processo histórico, da capacidade de representação das letras e do desenvolvimento das tecnologias.

A tipografia é mais do que uma linguagem, compreende um complexo sistema que situa-se entre a fronteira da significação das palavras e o próprio desenho. Assim, mesmo que a história oficial do design remeta a revolução industrial, um dos principais componentes das identidades visuais e design gráfico foi inventado bem antes e motivou pesquisas e criações desde de então. A estética da letra vem acompanhando as mudanças artísticas e de gosto desde da invenção da escrita, passando pelas letras góticas com arestas desenhadas até chegar nas letras digitais disponíveis para instalação em computadores.

No design, as letras são observadas como desenho e têm um papel diferente do que tem para um escritor. Um escritor não pensa em qual tipografia representa a história que está escrevendo da melhor forma. Como se o escritor criasse as histórias e o design ajuda-a a ser cantarolada, murmurada ou gritada.

Existem muitas formas de representar o mundo em que vivemos, o design apropria-se de muitas dessas linguagens, neste texto foram relacionadas, até o momento apenas quatro, porém esse número já permite explicar como uma logomarca é composta da sobreposição de várias linguagens. De fato, muitos elementos conversam durante a composição e a criação de uma identidade visual. Cada elemento que compõe uma marca pode ser analisado com fundamentos históricos, antropológicos, fisiológicos e psicológicos. Nesse fazer é possível compor com a linguagem verbal e visual, além de trabalhar a soma de forma, tipografia e cor. A combinação das fundamentações com a organização dos elementos e o próprio desenho resultarão na marca. Observa-se que todos esses fatores tornam a identidade criada em um signo não arbitrário, ou um signo que mantém alguma relação de semelhança com o objeto representado. Segundo Roman Jakobson (1995, p. 102) ‘O arbitrário é declarado o primeiro dos dois princípios gerais que permitem definir a natureza do signo lingüístico: 'O liame que une o significante ao significado é arbitrário'. O arbitrário é apenas uma das três possibilidades do signo, um signo concebido por uma ação projetual cria ligações lógicas e mantém uma identidade. Essas ligações lógicas podem ser relacionadas ao processo de concepção do design e a maneira como a informação é processada por ele.

\section{Repertório, organização e sobreposição de linguagens: aplicando as funções da linguagem} de Jakobson à uma marca.

Escolhemos analisar a marca do Banco Itaú. Junto ao design observa-se a ação da publicidade, pois, de certa forma ela atualiza a marca e faz com que se transforme em um signo traçado para manter relações de semelhança em algo arbitrário e instituído.

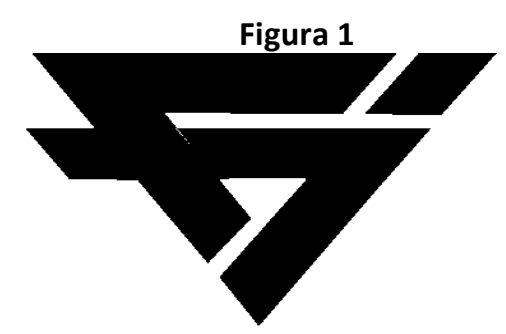


Fonte: WOLLNER, 2004, P.232.

Em 1966, o então Banco Federal Itaú Sul Americano, teve sua primeira identidade desenhada pela dupla Karl Heinz Bergmiller e Alexandre Wollner, ambos designers formados pela HfG. Entendemos que a solução encontrada tem grande relação com a escola onde os designers estudaram, é possível perceber, em sua forma final, influências do construtivismo.

As tendências construtivistas surgiram como respostas possíveis no plano da produção e, por extensão, no plano da ação cultural, a essa ruptura ocorrida em dois eixos: no meio da própria inteligência do trabalho de arte e no modo de sua inserção e circulação social. Daí o seu desenvolvimento obedecer linearmente a essa dupla preocupação; a questão sempre foi, para as ideologias construtivistas, construir uma arte que pudesse servir de modelo à própria construção social. (BRITO, 1999 p. 15)

No construtivismo percebe-se que a racionalidade, a economia de materiais, a disponibilidade de tecnologia bem como a necessidade de utilizar o potencial de informação influencia as produções e as formas.

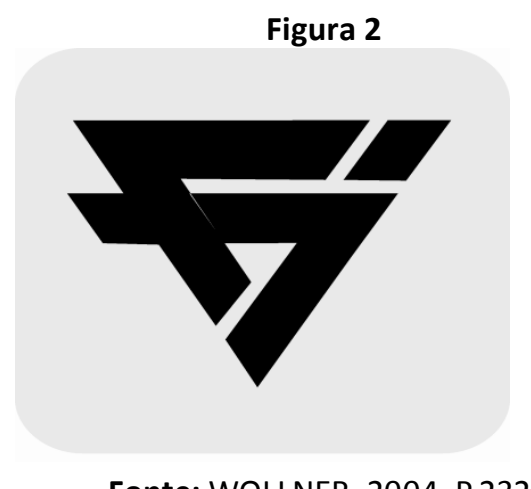

Fonte: WOLLNER, 2004, P.232.

Em fins dos anos sessenta, o designer Aloísio Magalhães inseriu uma espécie de bandeira de aço inox que funcionava como base para a marca ser fixada nas fachadas dos edifícios do banco.

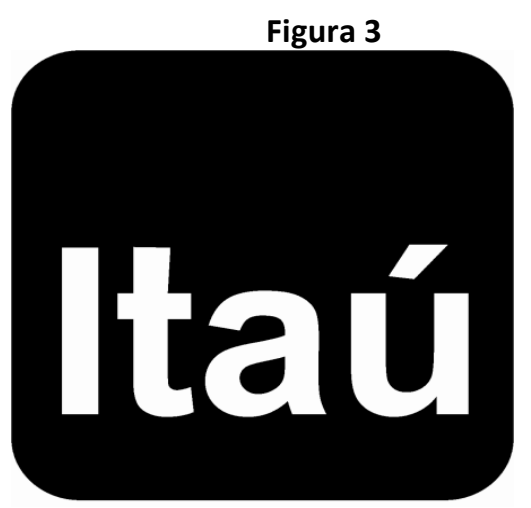

Fonte: WOLLNER, 2004, P.232.

Em 1970 Francesc Petit (*1934) transformou a marca inicial do Banco Federal Sulamericano Brasileiro em um logotipo, a mudança da razão social motivou a alteração da forma mas também fez refletir o significado da palavra Itaú que em tupi guarani significa "pedra preta". Além da fixação sobre a "pedra" o banco passou a ser representado pelo seu próprio nome grafado com em letra bastonada.

Em 1980 atendendo a um pedido de revitalização da marca o designer Alexandre Wollner propõe uma expansão do logotipo acrescentando uma tarja laranja atrás do retângulo preto com cantos arredondados. O contraste entre laranja e preto assegura visibilidade da marca e permite construir fachadas, ambientes internos e papelarias que serão reconhecidas com facilidade. 
A importância de criar uma marca não se faz por motivos estéticos, pela composição com cores e fundos, ou pela escolha dos tipos, mas sim na compreensão de que todos esses elementos formam um signo novo, ou uma forma de apresentação que nenhuma outra empresa tem e, mesmo sendo exclusiva, será reconhecida.

Para ser reconhecido, um signo precisa ter regularidade, apresentar-se sempre da mesma forma, com as mesmas cores, com o mesmo traço. Não é permitido a esse desenho lembrar, é necessário ser. Por vezes a grandiosidade de uma marca é tamanha que ela supera os limites físicos, a relação institucional e torna-se o maior patrimônio de quem a detêm.

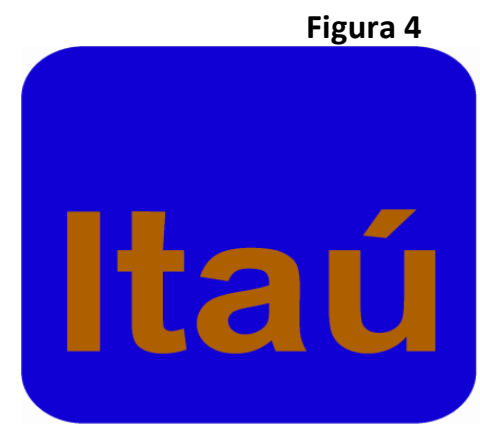

Fonte: marca do banco Itaú criada pela DPZ 2003.

Em 2003 a agência DPZ trocou a cor preta do retângulo por azul, a mudança parece ter sido motivada em função de novidades como o Internet Bank e a aproximação com as novas tecnologias. 0 fato é que com essa marca pode-se observar como a palavra Itaú deixa de representar "pedra preta" e passa a ser Itaú, o banco. Com essa mudança a marca passa a ser arbitrária, representar por instituição o banco e abandona a relação filológica entre palavra e desenho. Outro fator novo foi a escolha da cor azul para preencher o quadrado. Azul e Laranja são cores complementares, juntas elas correspondem a soma de todas as cores primárias fundamentais.

Pode-se ler a organização da marca como uma mensagem composta com pelo menos três eixos repertoriais e sintaxes primárias: cor, forma e tipo. Recuperando a proposta de sobreposição de camadas tem-se: o eixo $z$, onde a sobreposição torna-se uma forma de garantir significado à mensagem. Ao decompor a marca atual do banco tem se:

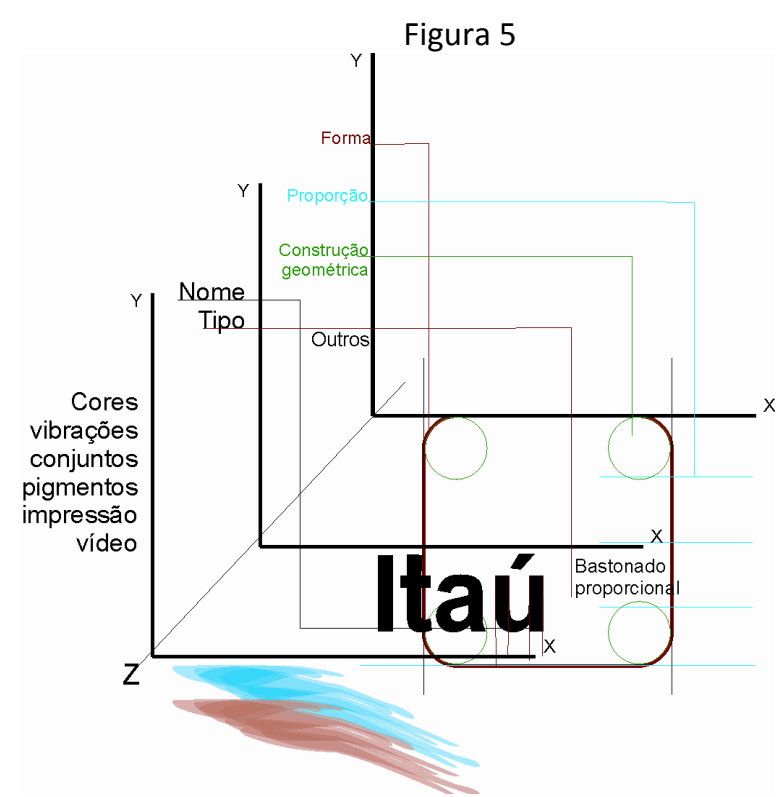

Fonte: sobreposição de eixos de seleção e composição de mensagens elaboradas a partir de diferentes códigos 
Quando elabora-se uma sintaxe baseada em uma única linguagem, sua organização opera com certa linearidade. Ao sobrepor essas linguagens estabelece-se uma malha estrutural com mobilidade em x, y e z e vínculo nos mesmos níveis, permitindo ampliar as funções da linguagem proposta por Jakobson. Isso se dá porque existe um mecanismo de poliglotismo cultural.

Ao elaborar uma marca utilizam-se várias linguagens que funcionam porque existem sobreposições de elementos de maneira quase 'metalingüísticas' (JAKOBSON, 1995, P. 127), traduzindo cada elemento da composição em outro, revelando nesse processo mais informações a respeito da coisa representada.

\section{Linguagens e funções do design na cultura}

Se na sua origem design foi pensado como uma forma de linguagem que permitia ao homem se comunicar com a máquina, ou uma forma de tradução de pensamento em linguagem humana e desse para a máquina, observa-se que quando associado à comunicação social o design opera como um filtro entre duas fronteiras: a dos elementos que existem em determinado produto/serviço e a população, fazendo o papel de linguagem única entre esses dois, embora cada um deles funcione como uma soma de mensagens. Ele pode ser pensado como linguagem múltipla que se decompõe em linguagem técnica, natural e artística. Basicamente são essas as funções da linguagem na cultura. O ponto mais importante ao se pensar design e linguagem é entendê-los como um sistema complexo que permite pensar e organizar as diversas linguagens presentes na cultura. Ao ler o design a luz desses conceitos observa-se que é do trânsito, ou da tradução de linguagem natural em artística e técnica que se compõe as linguagens do design. Como tradutores constante operam com vasta sobreposição de camadas pois a mesma mensagem tem que ser organizada para o usuário e para a máquina, emprestando elementos artísticos, históricos, antropológicos e do cotidiano.

Podemos representar um eixo semiótico onde em um dos seus extremos se dispõe em linguagem natural e no outro extremo os sistema poliestruturais do tipo de linguagem poética (e da arte em geral). Os textos reais navegam por esse eixo na dependência de seu domínio estrutural. Por fim, a percepção dos leitores pode, escolher um extremo dominante desprezando o texto da outra parte. (LOTMAN, 1996, v.1, P. 89)

Acompanhando o pensamento de Lotman é possível entender que o eixo semiótico pode ser representado da seguinte forma:

Arte___Língua Natural____Linguagem máquina

Dispostas na seguinte organização:

1. texto monoestrutural- texto homoestrutural e homogêneo;

2. texto heteroestrutual- heterogêno e composto de várias linguagens;

3. memória da cultural-poliglotismo que garantem o mecanismo de geração de sentido. (LOTMAN, 1996, v.1, P. 88)

Uma peça gráfica pode ser lida para obter informações rápidas, como composição poética ou como o processo metalinguístico que traduziu a mensagem pretendida. Na elaboração de uma mensagem gráfica são aproveitadas a linguagem poética, a função da língua natural e a metalinguagem e, o leitor pode acessar todas essas informações. Como mecanismo de metalinguagem as peças gráficas guardam informação sobre a sua confecção e trazem em si toda a história técnica da época de sua composição. Pode-se observar a diferença entre uma página produzida por Willians Morris no final do século XIX e uma produzida por Carson no final do século XX, além da função pretendida de informação, da composição poética, existe o reflexo de uma memória cultural concentrada na obra ou uma série de registros que permitem observar vestígios e costumes, bem como significados, sua forma de pensar e de agir. 
Figura 6

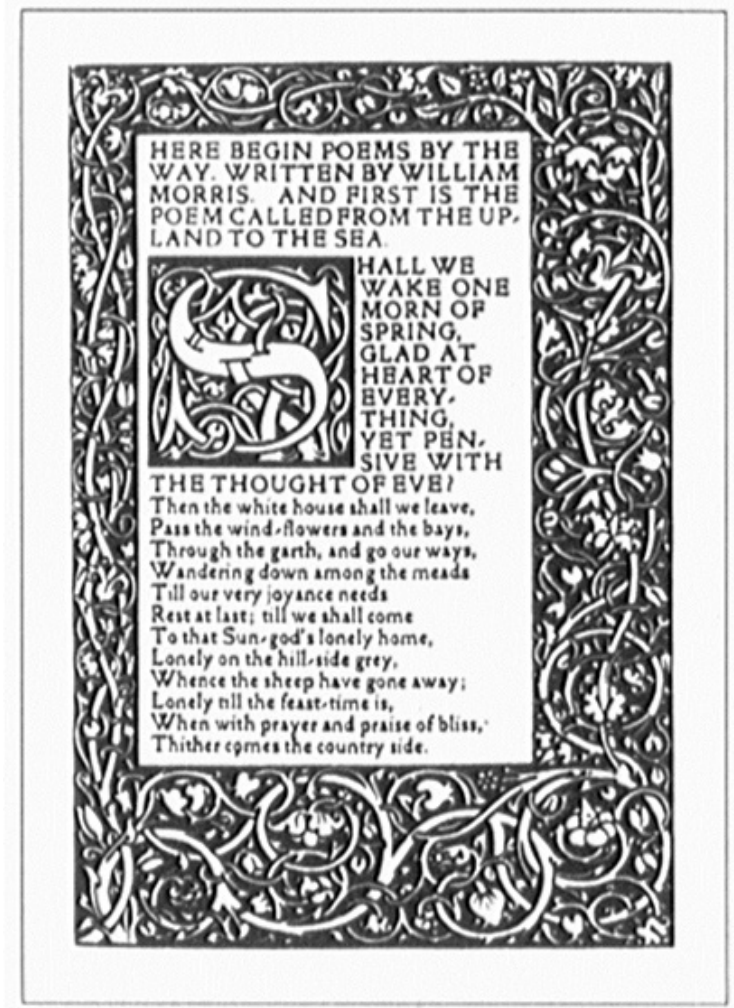

Fonte: Willian Morris, Poems By the Way 1897

Figura 7

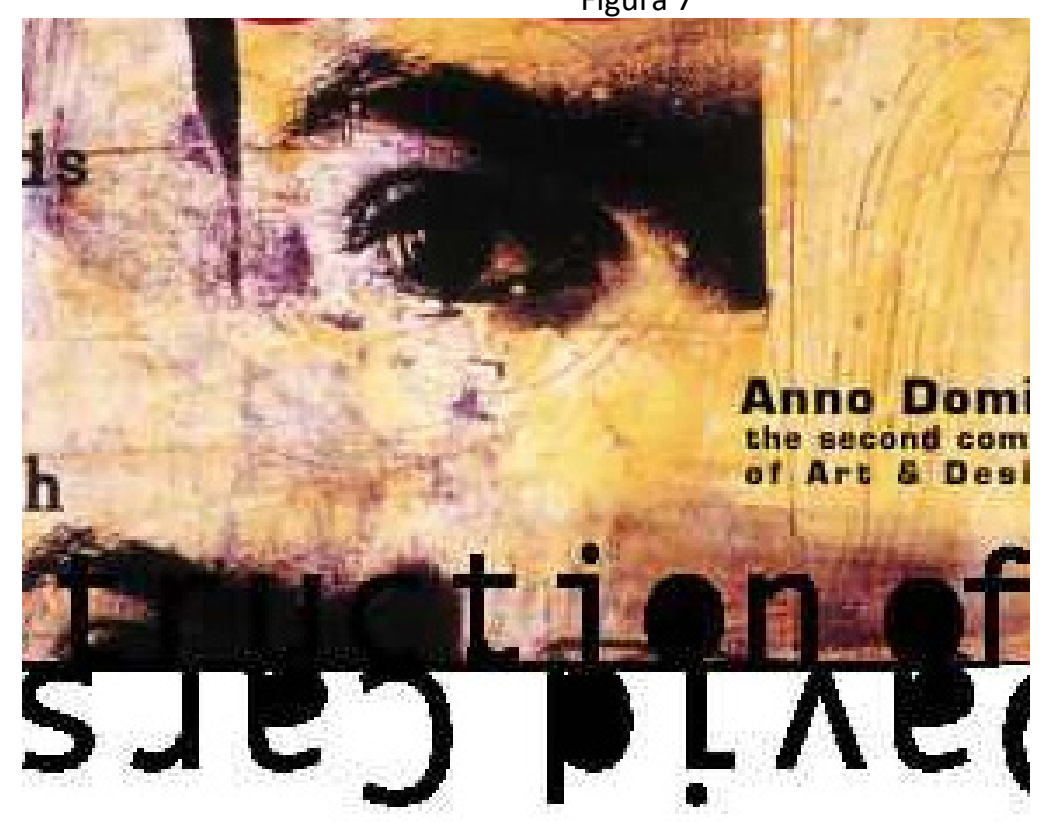

Fonte: Carson, David Carson, 2000.

Os trabalhos acima são compostos por elementos do design que refletem o tipo de tecnologia disponível em cada época. É possível identificar que no primeiro exemplo existem textos e desenhos dispostos sobre o papel, porém, um não ocupa o lugar físico do outro. Além, disso o desenho não 
expressa nenhuma informação presente no texto e cumpre função meramente decorativa. Já no segundo exemplo observa-se a relação de sentido entre a assinatura da peça e a imagem do autor, a página cumpre a função de informar como David Carson escreve com as linguagens do design gráfico, ao sobrepor uma vasta gama de elementos propondo uma multiplicidade de sentidos.

Quando observa-se a proposta de David Carson, ou mesmo a logomarca do banco Itaú surge uma relação de significados, permitindo a imagem exposta, já composta por várias linguagens conectarse ao pensamento do receptor gerando uma espécie de intersemiose que é o 'processo pelo qual um signo analisa as suas possibilidades espelhando-se em outros signos' (FERRARA, 1986, p.X).

A transformação de um signo em outro pela ação da decodificação do usuário permitirá ao designer a particularidade de uso, uma forma de subjetividade ou a constituição de uma linha tênue entre o design gráfico e a sua função semiótica.

\section{Concluindo}

A conexão entre o conceito de intersemiose e a sobreposição das linguagens no design sugere a existência de um tempo de entendimento, compreensão de sentido e elaboração de significados ou a diferença entre o antes e o depois, a própria ação do signo na percepção e na mente. Basicamente toda estrutura do design gráfico opera com a elaboração de uma mensagem nova, arranjada de tal forma, que o designer coloque nela toda sua experiência passada e o usuário retire dela a sensação futura de suas experiências.

Ao relacionar as funções da linguagem de Jakobson, a proposta de sobreposição das mesmas através do eixo $z$ e as funções da linguagem na cultura proposta por Lotman teremos:

Figura 8

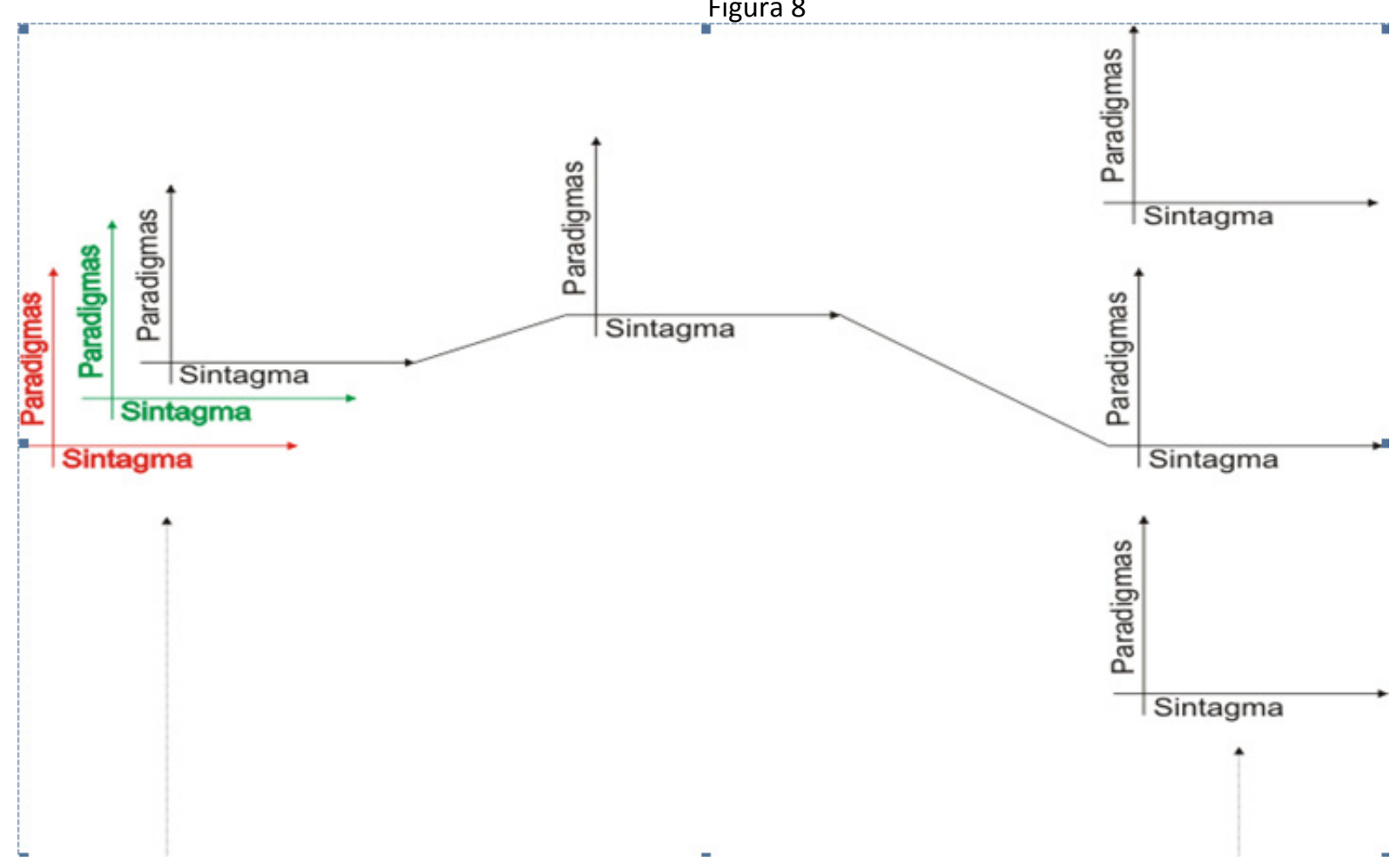

Fonte: Gráfico mostrando a sobreposição de linguagens do design, sua descrição em língua natural e sua decomposição em linguagem técnica para reprodução (elaborado para este artigo)

O design pode ser descrito por meio de uma linguagem natural e pode ser traduzido para linguagens técnicas. Estas não permitem sobreposição, pois, operam com uma quantidade mínima de 
informação. Prova disso é a transformação pelo computador de sistemas mais complexos em linguagens binárias. Por outro lado, dentro do próprio computador, existem programas que operam como uma mesa de composição, esses conseguem reconhecer várias formas de codificação e sobreposição de linguagens, porém essa mescla de linguagens acontece de acordo com a habilidade do próprio designer ou diagramador. Embora a elaboração de uma peça gráfica consiga-se mover de um extremo a outro, entre linguagem máquina, língua natural e arte, é na designação arte que o design reserva a maior quantidade de informações para compor o poliglotismo ou a memória da cultura.

\section{Notas}

${ }^{1}$ SANTOS, Fátima Aparecida. Linguagens do web design. São Paulo: Edgard Blucher, 2008.

\section{Referência}

ARGAN, Giulio Carlo. Arte moderna. São Paulo: Companhia das Letras, 1988.

BRITO, Ronaldo. Neoconcretismo: vértice e ruptura do projeto construtivo brasileiro. São Paulo: Cosac \& Naify, 1999.

FERRARA, Lucrécia D’ Aléssio. A estratégia dos signos. São Paulo: Ática, 1986. (Coleção Princípios)

JAKOBSON, Roman. Lingüística e comunicação. São Paulo: Cultrix, 1995.

LÓTMAN, luri M. La semiosfera I: semiótica de la cultura y del texto. Ed. Desidério Navarro. Madrid: Cátedra, 1996.

. La semiosfera II: semiótica de la cultura, del texto, de la conducta y del espacio. Ed.

Desidério Navarro. Madrid: Cátedra, 1996.

Cátedra, 1996.

. La semiosfera III: semiótica de las artes y de la cultura. Ed. Desidério Navarro. Madrid:

SANTOS, Fátima Aparecida. Linguagens do web design. São Paulo: Edgard Blucher, 2008.

WIENER, N. Cibernética e sociedade: o uso de seres humanos. São Paulo: Cultrix, 1993.

WOLLNER, Alexandre. Alexandre Wollner: design visual 50 anos. São Paulo: Cosac \& Naify, 2003. 